\title{
EVIDENCE FOR DETACHMENT FAULTING ON THE NE PARNASSOS MOUNTAIN FRONT (CENTRAL GREECE)
}

\author{
H.D. KRANIS ${ }^{1}$ AND D.I.PAPANIKOLAOU ${ }^{2}$
}

\begin{abstract}
The Mt Parnassos NE front (central-eastern mainland Greece) may owe its existence to the occurrence of a detachment fault, which is a re-used alpine overthrust surface. Neotectonic graben formation and segmented fault systems can be linked to this detachment fault, the reactivation of which could be attributed to the propagation of the dynamics of the Anatolian Block into the Aegean territory. The detachment kinematics is also confirmed through the use of a new kinematic indicator, formerly used only in metamorphic rocks.
\end{abstract}

\section{EYNOWH}

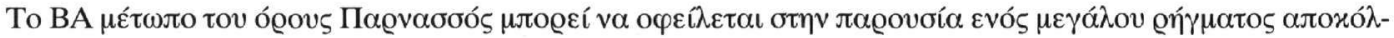

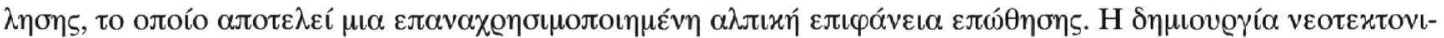

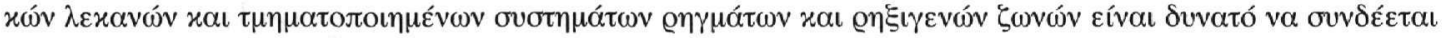

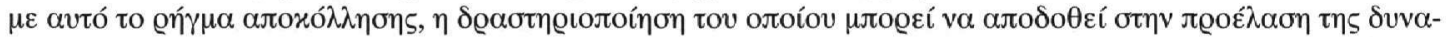

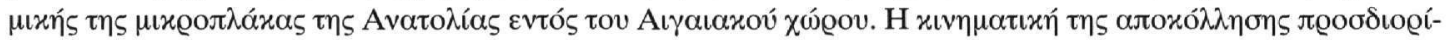

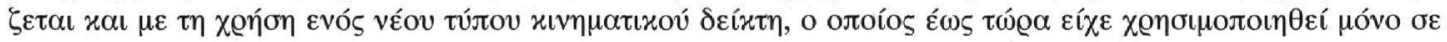

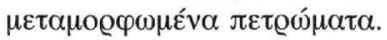

KEYWORDS: neotectonics, detachment fault, layering fish, Central Greece, Parnassos

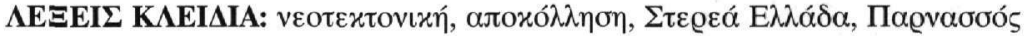

\section{INTRODUCTION}

The issue of the reuse of overthrust surfaces has been addressed by various researchers, usually in extending, post-orogenic intra-plate environments. The role of pre-existing overthrusts is crucial, since they are suitable weakness planes that can potentially be reactivated under a new stress regime (e.g. D' Agostino et al., 1998).

Central-Eastern Mainland Greece (Sterea Hellas) is an elongated landstrip between two actively deforming marine areas (Gulfs of Korinthos and Evoia in the south and north, respectively (Fig. 1), undergoing mean NNE-SSW extension since the Upper Pliocene (Jackson and McKenzie, 1988; Jolivet et al., 1994, and others). The region between the two, sub-parallel to each other, gulfs is characterized by an alpine nappe-pile structure, overprinted by neotectonic features (i.e. 'horst-graben' successions). The lowermost -and relatively autochthonous - nappe is that of Pindos Unit (Fig. 1). The Parnassos Unit (PU), which occupies the greatest part of central-eastern mainland Greece (CEMG) is "wedged" between the (underlying) Pindos and the (overlying) Sub-Pelagonian Units.

The neotectonic configuration of CEMG has been thoroughly studied since the 1970s (e.g Philip, 1974; Lemeille, 1977) and rigorous investigation continued into the following two decades (Jackson and McKenzie, 1983; 1988; Rondogianni-Tsiambaou, 1984; Stewart and Hancock, 1988; Roberts and Jackson, 1991; Leeder and Jackson, 1993; Jackson, 1994; 1999; Poulimenos \& Doutsos, 1996; Ganas, 1997 and others). The dominant neotectonic fabric includes WNW-ESE to E-W normal (or oblique-normal) segmented fault systems that exert significant influence on the relief, graben or half-graben formation and drainage. The results of these investigations, and in view of the recent advances in neotectonics, gave us the initiative to examine whether the observed neotectonic configuration is no more than the surficial expression of deeper, ongoing geodynamic processes, as already suggested by Jackson (1994).

1. Tectonic \& Applied Geology Department, Faculty of Geology, University of Athens, GR-157-84, Athens, Greece. e-mail:hkranis@geol.uoa.gr

2. Dynamic, Tectonic \& Applied Geology Department, Faculty of Geology, University of Athens, GR-157-84, Athens, Greece. email:dpapan@geol.uoa.gr 


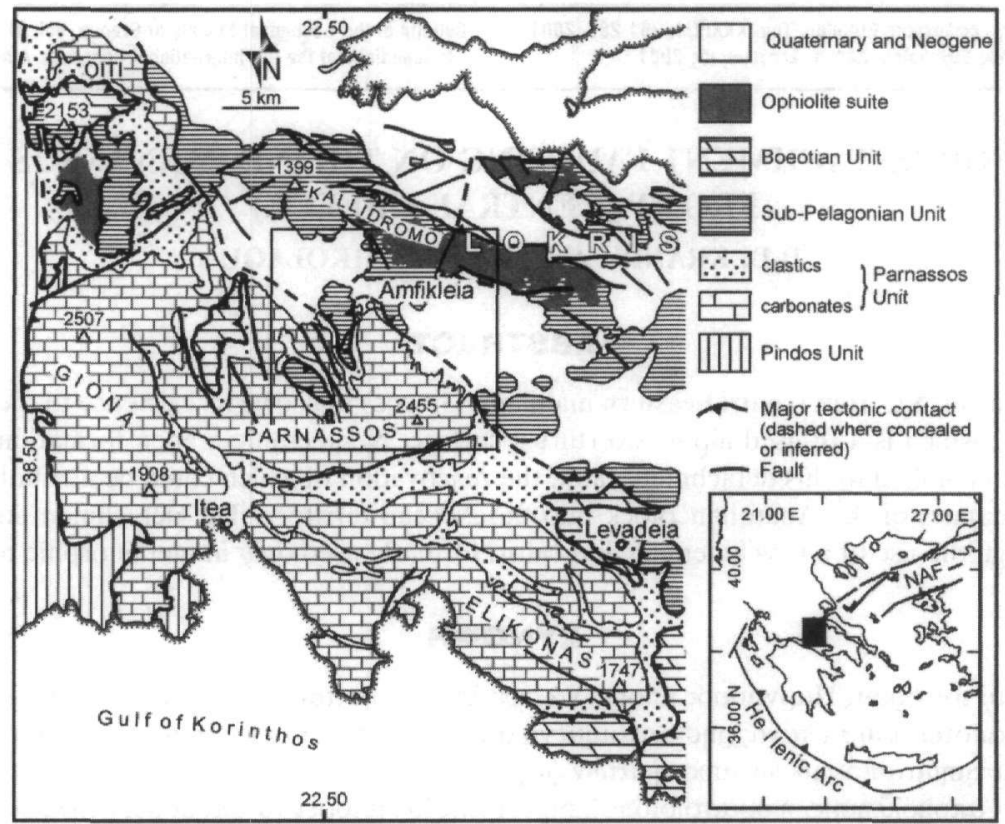

Fig. 1. Summary geological map of Central-eastern mainland Greece. Modified from Richter et al. (1996), with additions from Celet $(1962,1979)$ and Kranis (1999). Box indicates location of Fig 2. NAF: North Anatolian Fault.

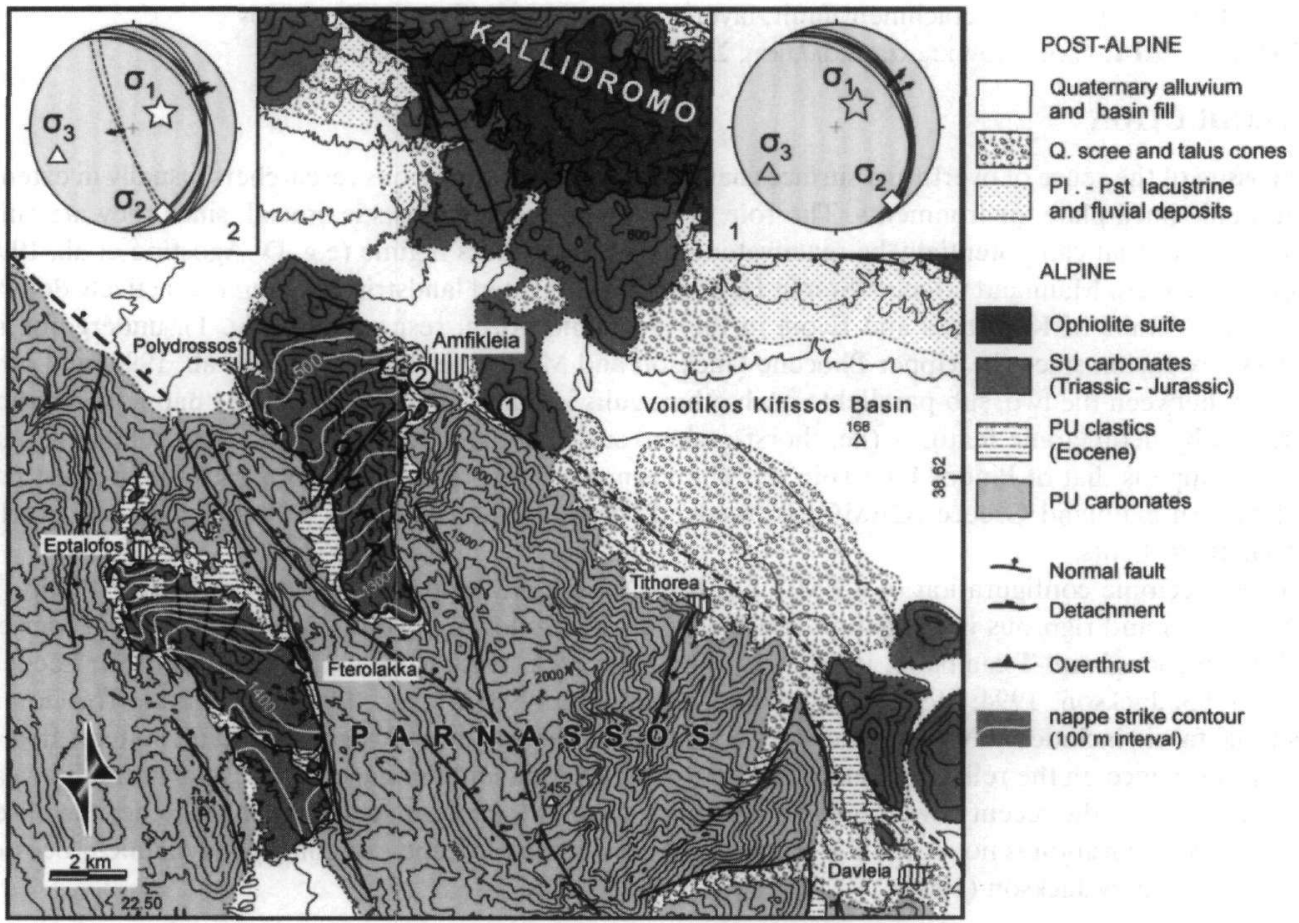

Fig. 2. Tectonic map of Mt Parnassos and environs. Insets 1 \& 2 are stereo-plots (equal area, l. hemisphere) of tectonic data (shear planes) from Dadi hill and Dadi monastery, respectively. Dashed great circles in projection 2 are hangingwall antithetic faults. SU: Sub-Pelagonian Unit; PU: Parnassos Unit. 
In this paper we shall try to show that a detachment fault may exist, in the form of a re-used alpine surface. We shall first give a brief outline of the alpine (and post-alpine) regional geological and tectonic setting; we shall then focus on the locations that provided data to support the notion of the reactivation of an alpine structure. Finally, the implications of this will be discussed, and an attempt will be made to link them with the existing active tectonic models.

\section{GEOLOGY - TECTONICS}

The alpine nappe sequence in central-eastern Mainland Greece (Sterea Hellas) comprises a relatively autochthonous unit (Parnassos Unit -PU) and relatively allochthonous one, the Sub-Pelagonian Unit -SU). PU is a 1500-2000 $\mathrm{m}$ thick neretic carbonate sequence (U. Triassic - Paleocene), terminating with a typical clastic sequence (flysch) at the Paleocene. SU comprises an U. Triassic - M. Jurassic carbonate platform that evolves into a M-L. Jurassic clastic sequence followed by U. Cretaceous carbonate sedimentation and flysch deposition in the Danian.

Mt Parnassos is built mostly of its namesake PU, while Mt Kallidromo consists of SU rocks and a tectonically emplaced ophiolitic suite. Relics/klippen of the SU are found within the Parnassos mountainous mass. One of them is the Polydrosso outcrop that extends from west of Amfikleia to Fterolakka, and another is the Eptalofo klippe, a few km SW of the former (Figs. 1,2). The tectonic positioning of these exposures was described by Richter et al. (1994, 1996) as nappe-graben ('Deckengraben'), indicating that they are now found within graben that have developed in the Parnassos mass soon after nappe emplacement ('tardi-tectonique' stage).

In Lokris, the trace of the surface that separates these two units marks the foot of the Mt Parnassos northern front, an impressive physiogeographic feature more than $2400 \mathrm{~m}$ high. The trace is found at the eastern edge of the mountain, close to Davleia (Fig. 2). Towards the NW, it is buried under the scree and talus cones at the NE front of the mountain, to emerge again a few km east of Amfikleia (Dadi hill). It then enters the mountain and climbs to an altitude of $1500 \mathrm{~m}$ (Fterolakka). At this point it starts to descend, until it eventually reaches an altitude of $\sim 450 \mathrm{~m}$, close to Polydrosso. Further to the west it is buried under the quaternary fill of the Voiotikos Kifissos basin and is found again at the eastern front of Mt Oiti (Fig. 1).

The kinematics of this surface was examined in a series of artificial or natural sections, located at the northwestern and northeastern parts of Mt Parnassos. In spite, however, of the sufficient number of sections, only a handful were suitable for data collection, either because of their orientation (usually strike-parallel) or condition (covered by debris).

\section{AMFIKLEIA AND DADI HILL}

A quarry exposure at Amfikleia (Location 1 in Fig. 2) gave us the possibility to study the kinematics of this surface and the associated shear zone. The quarry is located in a saddle that separates the main mountainous mass from a small hill (Dadi hill) east of Amfikleia. The trace of the surface runs next to the axis of the shoulder, somewhat offset towards the hill, whose maximum altitude is $565 \mathrm{~m}$.

Dadi hill is built of whitish tectonized Triassic dolomites, which belong to the base of the Triassic-Jurassic carbonate platform of the SU, overlain by frequently dolomitized L.-M. Jurassic medium-bedded limestones. On the other hand, the outcrops at the foot of Mt Parnassos comprise Cretaceous - Eocene limestones, overlain by a thin (a few tens of $\mathrm{m}$. at this location) zone of clastic deposits (pelites, sandstones and marls) that belong to the flysch of the PU. The local bedding is moderately dipping -30/030.

The quarry exposure revealed a well-defined tectonic surface, with a dip of $30-32^{\circ} / 060^{\circ}$, the hanging wall of which consists of the SU dolomites and the footwall of the PU flysch. The deformation fabric in the footwall clastic sediments displays alpine compressional characteristics overprinted by top-to-the northeast extensional structures and associated fabric. These features include (i) S-C fabric (Fig. 3), (ii) cm-scale $\sigma$-type porphyroclasts (Fig. 4) and (iii) a structure equivalent to the "foliation fish" (Fig. 3) (Hanmer, 1986; Davis \& Reynolds, 1996, fig. 9.61) that develops within sheared metamorphic rocks; however, and since in this case the rocks are not metamorphosed, we can use the term "layering fish", a structure that carries the same kinematic significance attributed to its "metamorphic" counterpart. All the aforementioned indicate top-to northeast movement, postdating the original compressional-type deformation, associated with Tertiary nappe emplacement. Small-scale fractures, located both on the hanging- and the footwall, were also found, a few $\mathrm{cm}$ over and under the main tectonic plane. These fractures are oblique to the main tectonic surface, with a NE-trend and dips of $32-35^{\circ} \mathrm{NW}$. The striations on them are gently plunging $\left(20-25^{\circ} \mathrm{W}\right)$ and characterize the fractures as oblique-normal. 


\section{POLYDROSSO}

On the road connecting Amfikleia with Fterolakka there are several road cuts that expose the SU/PU tectonic contact, the footwall of which consists invariably of the PU clastics, while the hanging wall comprises SU carbonates of varying degrees of deformation, from moderately brecciated to pulverized limestones and dolomites. Along a 300-m long, straight road cut, the surface itself displays a sinuosity with a "wavelength" of 60-90 m, while gently dipping $\mathrm{N}$ to NNW; the estimated curvature axis is oriented roughly in this direction.

The surface is very well exposed close to Dadi monastery (Location 2 in Fig. 2). Its local dip and dip direction vary between $30 / 100$ and 30/075, while striations on it have a gentle northeasterly plunge (average: $20 / 066$ ). The incompetent footwall rocks are intensely deformed. Here we could observe extensional S-C fabric within the footwall clastics, just under the tectonic contact. Within the competent/brittle hangingwall rocks, a system of faults antithetic to the main tectonic contact has developed (Fig. 2)

Similar, but less well-preserved exposures can be seen all along the road that connects Amfikleia with Fterolakka, from $500 \mathrm{~m}$. west of the town and for a few $\mathrm{km}$ to the south, up to an altitude of ' $800 \mathrm{~m}$. Further to the south, and up to the highest point of the contact $(1500 \mathrm{~m})$ no visible signs of extensional deformation were observed along the tectonic contact.

Along the western part of Toufa, there are no exposures to help us clarify the kinematics of the SU/PU contact, as dense forest and debris-covered slopes have obliterated the few natural or man-made cuts. However, some few hundreds of $\mathrm{m}$ east of Ano Polydrosso, a large fault with an exposed 30-50 m.-high sub-vertical slickenside was found. This fault seems to be limited within the hanging wall only, with its continuation in the footwall being unlikely.

\section{STRIKE-CONTOUR MAP}

We constructed a strike-contour map for the base of the detachment (Fig. 2), a procedure that aided in the interpretation of the neotectonic behaviour of this surface and the SU/PU relationship. As shown in Fig.2, the

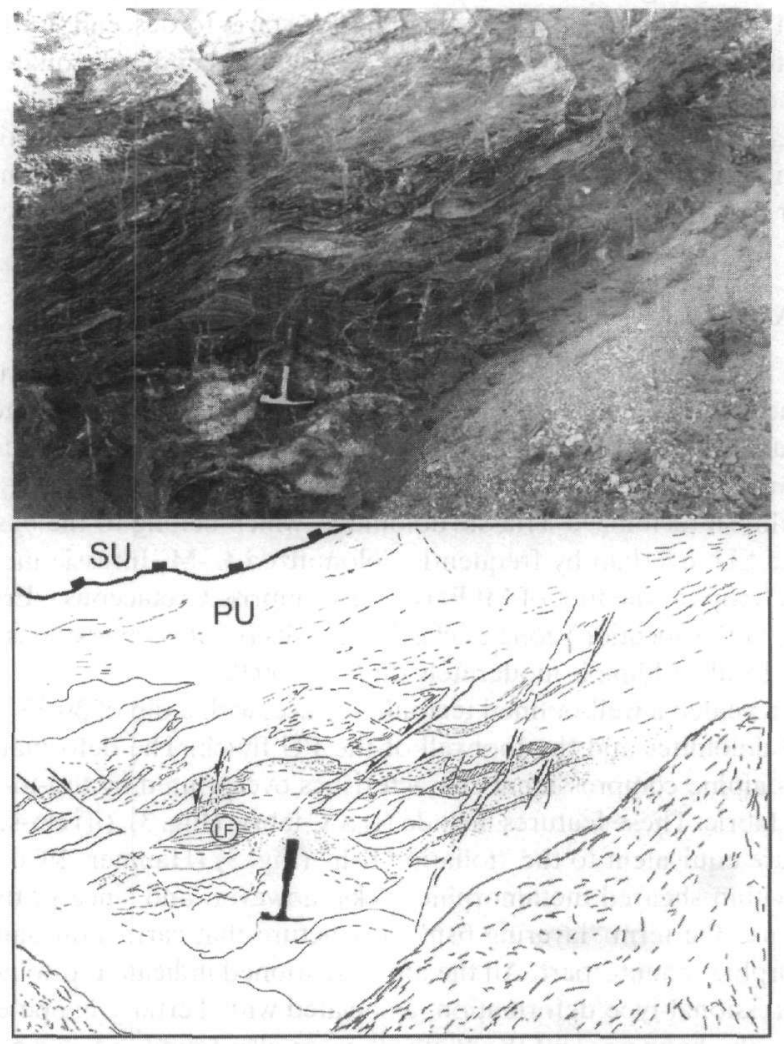

Fig. 3. Deformed footwall clastic sediments, just under the main detachment surface (top left). View to the SE. S-C shears overprint compressional-type features, as tight folds and associated minor thrusts, related to Tertiary nappe emplacement.

Secondary/ antithetic C'have also developed (center left). Note "layering fish" (LF) to the left of hammer. View to E. 
(basal plane of the) tectonic contact, which reaches a maximum altitude of $+1500 \mathrm{~m}$, dips NNW, until it gets buried under the quaternary cover of Voiotikos Kifissos Basin. The lower (northern) part of it seems slightly more deformed than the southern one, as it displays a gentle antiformal warping with a NNW-plunging axis (Fig. 2). On the other hand, its higher (southern) part shows a steady NNW-ward dip (approx. $9.7^{\circ}$ ), which locally increases at the southernmost edge of the outcrop (between 1400 and $1500 \mathrm{~m}$ ). In this sense, the Polydrosso outcrop can be divided into two portions, separated by the Toufa fault, which was described in the previous section. However the Toufa fault (Fig. 2), does not seem to affect the base of the detachment, which is supported both by field observations and the strike-contour map (the contours are practically unaffected by the fault). Therefore, we believe it is not a neotectonic structure, as also seems to be the case of the faults located within the nearby Eptalofos klippe.

If we focus on the lower part of the Polydrosso exposure, we can see that the 500-m contour line could continue unbroken from Polydrosso to Dadi hill (and presumably further to the SE up to Davleia). The same could be true for the $600-\mathrm{m}$. and $700-\mathrm{m}$. (or even the $800-\mathrm{m}$.) contours, had the hangingwall not been eroded. This indicates that the Polydrosso outcrop (or at least the northern part of it) has not been separated from the Dadi exposure and, therefore, from the Kallidromo mass. On the contrary, the Eptalofos klippe has a different geometry (Fig. 2) and is clearly cut off from the SU mass.

\section{CONSOLIDATION - DISCUSSION}

It has been suggested that the northeastern face of Mt Parnassos is a large neotectonic normal fault, mostly on the basis of morphotectonic data (e.g. Ganas and White, 1996). While this is valid from the geomophological point of view, it is rather precarious from the geological and tectonic viewpoint. Mt Parnassos is built of the

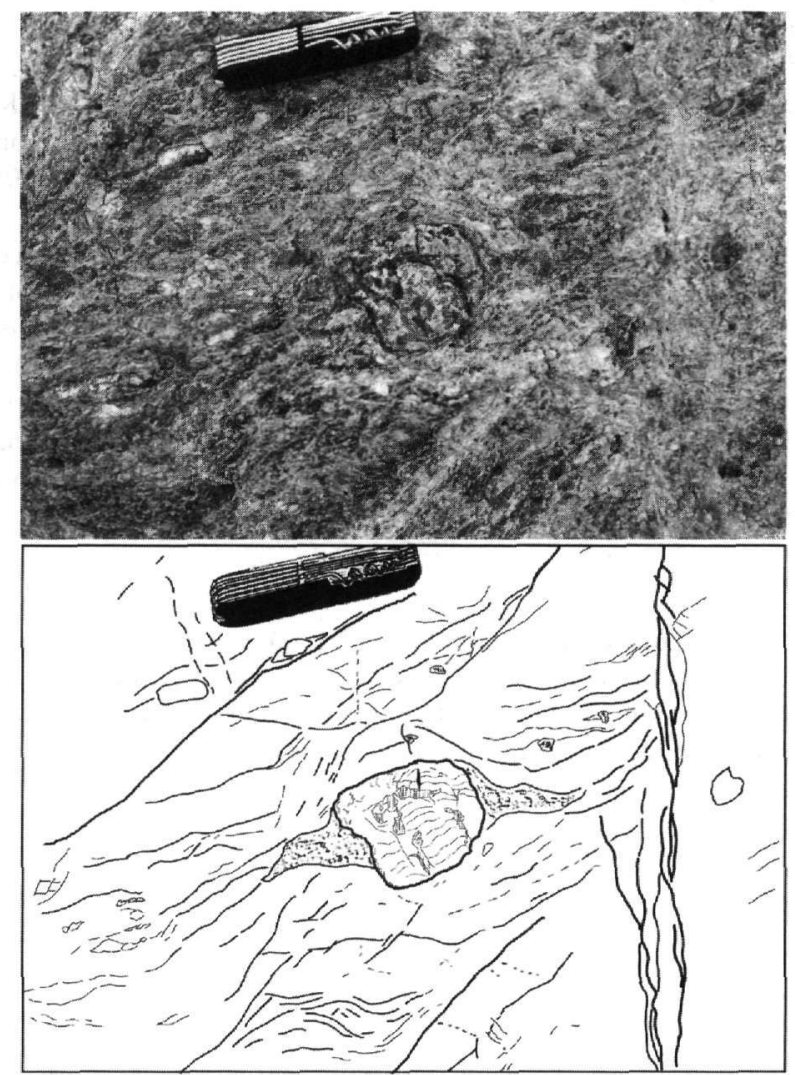

Fig. 4. Deformation fabric ( $S$-C) within the footwall clastics of the $P U$, including $\mathrm{cm}$ - and $\mathrm{mm}$-scale $\sigma$-type clasts (center and below swiss-army knife, respectively), all showing extensional (top-to northeast) deformation. View to SE. Note also vertical fault (strike-slip) at right of figure. 
rocks that belong to the PU and reaches an altitude of $2455 \mathrm{~m}$. The relatively allochthonous SU forms the basement of the adjacent basin of Voiotikos Kifissos and some outcrops of it emerge from the basin fill in the form of small hills, adjacent to the foot of the mountain front, with a maximum altitude of $565 \mathrm{~m}$. Thus, the SU/ PU boundary would be expected to be buried under the Voiotikos Kifissos Basin. Had this contact been cut by a range-bounding fault, one should have expected that the Polydrosso outcrop would have been cut off and uplifted, belonging now in the footwall of a large normal fault. However, the strike-contour map of Fig. 2 shows that this is no the case and the Polydrosso exposure has not been cut off from the main body of the SU mass, exposed on Mt Kallidromo (Figs. 1 and 2).

Besides, close inspection of the deformation structures along (and close to) the SU/PU tectonic contact show clear signs of extensional, top-to-northeast movement, expressed in the form of S-C fabric, sheared o-type clasts and "layering fish" (Figs. 3, 4). Secondary, albeit important, structures, such as minor oblique extensional fractures and hangingwall antithetic faulting, support the aforementioned notion. Another observation that may corroborate this argument is that the mean slope of the Mt Parnassos NE front is $\sim 22-24^{\circ}$ (for the part between 300 and $1700 \mathrm{~m}$ ), a value close to the dip of the detachment at its frontal part, on Dadi hill. We should also note the consistency in the orientation of the stress axes, as they were obtained using the Angelier's (1984) inversion method, in the two data stations (Fig.2).

The kinematic indicators, backed by the geomophological observations, support the notion that the originally compressional-style surface (thrust) has been reactivated as a detachment fault. Such a notion was expressed by Jackson (1994), but no evidence of re-used thrusts was found then, while a similar perspective was given by Sorel (2000) for the Korinthos - Patra rift. The flysch in the footwall (PU) constitutes the appropriate mobile material that facilitates this retro-sliding, and the hanging-wall SU carbonates display various degrees of deformation. Within the former, S-C fabric and associated extensional structures have develop, while the latter host secondary, antithetic faults.

Having these in mind, it could be suggested that the SU slides towards the NE (on average), on its contact with the underlying PU. Most WNW-ESE neotectonic faults in Lokris could root into this detachment: the intense segmentation of these faults, with segment lengths rarely exceeding $8 \mathrm{~km}$ (Kranis, 1999), and the progressive increase in the dip of synthetic (NNE-dipping) faults as we move away from the Parnassos front and towards the Gulf of Evoia -in a similar fashion as the one presented by Sorel (2000) - suggest that the major graben-bounding faults could branch off an underlying detachment.

Here we need to stress the fact that the kinematics of the detachment, as evidenced by the Amfikleia quarry exposure, displays a sense of obliquity. In other words, the magnitude of sliding along the strike of the detachment (and at least for its frontal part) may not be uniform. Although no solid evidence has been found yet, it could be suggested that the finite sliding decreases towards the west. In this sense, the hangingwall slides under the influence of gravity and also rotates around a (sub)vertical axis. This could have resulted from the SW-ward propagation of dynamics of the Anatolian block(Fig. 1) into the Aegean region (Senger, 1979; Mariolakos and Papanikolaou, 1987; Westaway, 1991; Jackson, 1994), which leads to counter-clockwise rotation of rigid to semirigid fault blocks in central-eastern Mainland Greece.

\section{ACKNOWLEDGEMENTS}

We thank D. Mountrakis (Univ. of Thessaloniki) and T. Doutsos (Univ. of Patras) for their constructive reviews of the manuscript. Valuable comments and discussions in the field work were provided by Manolis Skourtsos and Sia Bakopoulou (Univ. of Athens); Dimitris Sakellariou (National Center for Marine Research) is also thanked for his useful comments on the structural analysis of the data. 


\section{REFERENCES}

ANGELIER, J. 1984, Tectonic analysis of fault-slip data sets: Journal of Geophysical Research, 89, no B7, p. 58355848.

CELET, P., 1962, Contribution a l'étude géologique du Parnasse-Kiona et d' une partie des régions méridionales de la Grèce continentale: Annales Géologiques des Pays Hélleniques, XIII, p. 1-446.

CELET, P., 1979, Les bordures de la zone du Parnasse (Grèce). Évolution palaeogeographique au Mesozoique et charactères structuraux, in Proceedings II, VI Colloquim on the Geology of the Aegean Region, Athens, p.725-740.

D' AGOSTINO, N., CHAMOT-ROOKE, N., FUNICIELLO, R, JOLIVET, L., and SPERANZA, F., 1998, The role of pre-existing thrust faults and topography on the styles of extension in the Gran Sasso range (central Italy): Tectonophysics, v. 292, p. 229-254.

DAVIS, G.H. and REYNOLDS, S.J., 1996, Structural geology of rocks and regions: New York, J. Wiley and Sons Inc., $776 \mathrm{p}$.

GANAS, A., 1997. Fault segmentation and seismic hazard assessment in the Gulf of Evia rift, Central Greece. Unpubl. $\mathrm{PhD}$ Thesis, Univ. of Reading, $369 \mathrm{p}$.

GANAS, A. and WHITE, K., 1996, Neotectonic fault segments and footwall geomorphology in Eastern Central Greece from Landsat TM data: Geological Society of Greece Special Publication, 6, p. 169-175.

HANMER, S., 1986, Asymmetrical pull-aparts and foliation fish as kinematic indicators: Journal of Structural Geology, v. 2, no. 2, p. 111-122.

JACKSON, J, 1994, Active tectonics of the Aegean region: Annual Review of Earth and Planetary Science, 22, p. 239271.

JACKSON, J. and D. McKENZIE, 1983, The geometrical evolution of normal fault systems, Journal of Structural Geology, 5, p. 471-482.

JACKSON, J. and McKENZIE, D., 1984, Rotational mechanisms of active deformation in Greece and Iran, in J.E. Dixon and A.H.F. Robertson eds., The geological evolution of the eastern Mediterranean, Geol. Soc. [London] Special Publication, 19, p. 743-754.

JOLIVET, L., BRUN, J.P., GAUTIER, P., LALLEMANT S., and PATRIAT, M., 1994, 3-D kinematics of extension in the Aegean region from the early Miocene to the Present, insights from the ductile crust: Bulletin Societé Géologique de France, v. 165, no. 3, p. 195-209.

KRANIS, H.D., 1999, Neotectonic activity of fault zones in Lokris, central-eastern mainland Greece [PhD thesis]: Athens, University of Athens, $234 \mathrm{p}$.

LEEDER, M.R. and JACKSON, J.A., 1993, The interaction between normal faulting and drainage in active extensional basins, with examples from the western United States and central Greece: Basin Research, 5, p. 79-102.

LEMEILLE, F., 1977, Études néotectoniques en Grèce Centrale Nord-orientale (Eubée Centrale, Attique, Beotie, Locride) et dans les Sporades du Nord (ile de Skiros) [These $3^{\text {eme }}$ degre]:, Universite Paris XI - Centre d' Orsay, $173 \mathrm{p}$.

MARIOLAKOS, I., and PAPANIKOLAOU, D., 1987, Type of deformation and relationship between deformation and seismicity in the Hellenic arc: Bulletin of the Geological Society of Greece, XIX, p. $59-76$ [in Greek]

PHILIP, H., 1974, Etude néotectonique des rivages égéens en Locride et Eubée nord-occidentale (Grèce), [Thèse de Docteur]: Académie de Montpelier, 86 p.

POULIMENOS, D. \& DOUTSOS, T., 1996. Barriers on seismogenic faults in central Greece. Journal of Geodynamics, 22, 119-135.

RICHTER, D., MÜLLER, C., and RISCH, H., 1994, Die Flysch-Zonen Griechenlands IX. Der böotische OberkreideFlysch im nördlichen Parnass und im nordwestlichen Kallidromon-Gebirge (Griechenland): Zeitschrift der geologisches Gesselschaft, v. 145, p. 274-285.

RICHTER, D., MÜLLER, C., MIHM, A. and RISCH, H., 1996, Die Flysch-Zonen Griechenlands XII. Das Böotikum und seine Flysche im Bereich des Iti - Parnass - Elikon Gebirges, des nordwestlichen Kallidromon Gebirges und des südwestlichen Othrys - Gebirges (Mittelgriechenland): Neues Jahrbook de Geologie und Paläontologie Abhandlung, v. 201, no 3, p. 267-409.

ROBERTS, S. and JACKSON, J., 1991, Active normal faulting in central Greece: an overview, in Roberts, A.M., Yielding G., and Freeman B., eds., The Geometry of Normal Faults: Geological Society [London] Special Publication, 56, p. 125-142.

RONDOYIANNI - TSIAMBAOU, TH., 1984. Étude néotectonique des rivages occidentaux du canal d'Atalanti (Grèce centrale). [These $3^{\text {eme }}$ cycle]: Université de Paris Sud, Centre d'Orsay, $190 \mathrm{p}$.

SENGÖR, A.M., 1979, The North Anatolian Transform fault: its age, offset and tectonic significance: Journal of the Geological Society [London], 136, p. 269-282.

SOREL, D., 2000, A Pleistocene and still-active detachment fault and the origin of the Corinth-Patras rift, Greece: Geology, v. 28, 1, p. 83-86.

WESTAWAY, R., 1991, Continental extension on sets of parallel faults: observational evidence and theoretical models, In Roberts, A.M., Yielding G., and Freeman B., eds., The Geometry of Normal Faults: Geological Society [London] Special Publication, 56, p. 143-169. 